\title{
Case: Quality Of Student's Content Writing Through Implementation Of Project Based Learning Model In Biology
}

\author{
Anita Indriani ${ }^{1)}$, Sri Widoretno ${ }^{2)}$, Sri Dwiastuti ${ }^{3)}$ \\ Pendidikan Biologi FKIP Universitas Sebelas Maret Surakarta, \\ J1. Ir. Sutami 36 A, Surakarta, 57126, Kentingan, Surakarta, Indonesia \\ Surat elektronik: anitaindriani28@gmail.com*, widoretnosri@gmail.com, dwiastuti54@gmail.com \\ *coresponding author
}

\begin{abstract}
ABSTRAK
Penelitian bertujuan meningkatkan kualitas konten tulisan peserta didik melalui penerapan model Project Based Learning pada pembelajaran Biologi. Penelitian merupakan Penelitian Tindakan Kelas (PTK) dengan subjek penelitian adalah peserta didik kelas XI MIPA 6 SMA Negeri 4 Surakarta berjumlah 32 peserta didik. Penelitian dilaksanakan secara bersiklus dengan tahap: perencanaan, pelaksanaan, pengamatan, dan refleksi. Data penelitian diperoleh melalui observasi, dokumentasi, dan wawancara, yang dilengkapi dengan rubrik writing skills. Validasi data menggunakan teknik triangulasi metode. Teknik analisis data menggunakan analisis deskriptif kualitatif: reduksi, penyajian, dan verifikasi data. Hasil penelitian menunjukkan peningkatan kualitas konten tulisan peserta didik selama penerapan model Project Based Learning pada pembelajaran Biologi.
\end{abstract}

Kata kunci: model project based learning, kualitas konten tulisan

\begin{abstract}
The research aims to improve the quality of student's content writing in biology through implementation of Project Based Learning model. The research is a Classroom Action Research (CAR) with the subjects of this research were students of class XI MIPA 6 SMA N 4 Surakarta are 32 learners. Research conducted by the cyclical phases: planning, implementation, observation, and reflection. The research data was collected through observation, documentation, and interviews, which are equipped with a writing rubric skills. Data validation method using triangulation techniques. Data were analyzed using qualitative descriptive analysis: reduction, presentation, and verification of data. The results showed an increase in the quality of learners writing the content for the application of the model Project Based Learning in learning biology.
\end{abstract}

Keyword: discovery learning, biology learning

Copyright (C) 2017 Universitas Ahmad Dahlan

\section{Pendahuluan}

Proses pembelajaran berfungsi melatihkan keterampilan yang dibutuhkan peserta didik di abad 21, salah satunya keterampilan berkomunikasi secara tertulis (Kyllonen, 2012). Komunikasi secara tertulis merupakan sarana memberikan informasi yang disampaikan dalam bentuk tulisan. Tulisan yang disusun perlu memperhatikan bahasa dan konten penulisan yang sesuai supaya informasi diterima dan dipahami dengan tepat oleh pembaca (Mclean, et al., 2012; Suciu, Simon \& Kilyeni, 2014).

Tulisan sebagai salah satu hasil kegiatan metakognitif kompleks mampu menggambarkan pengetahuan individu, keterampilan dasar, strategi, dan kemampuan mengkoordinasi beberapa proses (Thanh Huy, 2015). Tulisan berfungsi untuk mentransformasikan pengetahuan, meningkatkan pemahaman, membangun refleksi diri, memecahkan masalah, dan pengembangan kemampuan berpikir kritis peserta didik (Bailey, et al., 2015).

Tulisan dalam proses pembelajaran merupakan produk visualisasi ide dari peserta didik yang menjadi salah satu penilaian guru untuk mengevaluasi penguasaan konten dan penalaran peserta didik (Lestari, 2009; Yusefni \& Sriyati, 2015). Tulisan sebagai produk visualisasi ide dibangun melalui proses pembelajaran yang menghadirkan fenomena dan mengakomodasi peserta didik untuk merumuskan masalah dengan memunculkan pertanyaan kritis (Bailey, et al., 2015). Tulisan dengan pemahan kritis disusun oleh peserta didik dengan mengaitkan ide eksplisit melalui pemilihan dan evaluasi informasi yang diperoleh (Quitadamo \& Kurtz, 2007). Chikita, Padmadewi, dan Suarnajaya (2013) mengungkapkan bahwa tulisan yang disusun dengan mengaitkan kualitas ide, pemahaman topik yang dipilih, dan penataan ide pada produk tertulis sebagai penilaian kemampuan kognitif mampu dianalisis berdasarkan kualitas konten tulisan.

Hasil analisis kualitas konten tulisan berdasarkan observasi tulisan peserta didik pada pelaksanaan pembelajaran Biologi di kelas XI MIPA 6 SMA Negeri 4 Surakarta diketahui $33,33 \%$ di level 1 skor 2 dan $20,83 \%$ di level 1 skor 3 . Analisis kualitas konten 
tulisan dilakukan dengan menggunakan rubrik writing skills menurut Mclean, et al. (2012).

Mclean, et al. (2012) menyatakan kualitas konten tulisan pada level 1 skor 2 menunjukkan tulisan peserta didik belum mampu menyampaikan informasi atau pesan nyata yang sesuai dengan tujuan penulisan. Kualitas konten tulisan pada level 1 skor 3 menunjukkan tulisan peserta didik menyampaikan informasi atau pesan nyata yang sesuai dengan tujuan penulisan.

Tulisan sebagai sarana menyampaikan informasi dalam proses pembelajaran dilatihkan melalui beberapa kegiatan yang memfasilitasi peserta didik untuk memvisualisasikan ide dalam bentuk tulisan. Chakravarthi dan Haleagrahara (2010) mengungkapkan bahwa tulisan sebagai visualisasi ide mampu dihasilkan melalui penghadiran fenomena pada proses pembelajaran yang mengarahkan peserta didik untuk merumuskan masalah. Rumusan masalah yang disusun tidak terlepas dari pertanyaan dan pernyataan penuntun guru yang memfokuskan tindakan peserta didik untuk memecahkan masalah (Turgut, 2008). Pemecahan masalah yang diperoleh dari proses berpikir dan penalaran, mampu dituliskan peserta didik dalam bentuk perencanaan solusi (Brown, Lawless \& Boyer, 2013). Solusi yang direncanakan mengarahkan peserta didik untuk melaksanakan sebuah proyek yang dalam proses penyelesaian memerlukan interaksi konten dan penyelidikan terkait informasi pendukung untuk pendesainan proyek (Cakiroglu, 2014).

Desain proyek yang dikerjakan peserta didik dan laporan tertulis mengenai pengerjaan proyek sebagai wujud dari komunikasi tertulis adalah salah satu modal untuk melaksanakan kegiatan presentasi (Demirbag \& Gunel, 2014). Kegiatan presentasi yang dilaksanakan peserta didik menjadi kesempatan pengembangan keberhasilan diri peserta didik terhadap kedalaman dan kebermaknaan informasi (Brown, et al., 2013). Informasi yang telah disampaikan selanjutnya dianalisis dan dirumuskan dalam sebuah kesimpulan. Perumusan kesimpulan dilaksanakan dengan menghubungkan beberapa variabel melalui proses penalaran yang divisualisasikan dalam bentuk tulisan (Dwyer, Hogan \& Stewart, 2011).

Kegiatan menemukan dan memecahkan masalah, melakukan perencanaan, penyelidikan, pendesainan proyek, dan perumusan kesimpulan, yang mengakomodasi peserta didik untuk menghasilkan tulisan ditemukan pada tahapan model Project Based Learnig (PjBL) (Cakiroglu, 2014). PjBL merupakan model pembelajaran yang mengakomodasi peserta didik untuk melakukan kegiatan kompleks berupa tugas-tugas bermakna yang mampu menghasilkan produk nyata (Karina, Sadia, \& Suastra, 2014). PjBL menurut Turgut (2008) memiliki 5 tahapan dalam proses pembelajaran, yaitu: 1) planning an investigation process according to driving question, 2) searching for the theoretical background of the driving question, 3) presenting that theoretical background to class and discussion about issue, 4) deciding the study group the way of collecting data and data analysis, 5) evaluating data, arriving a conclusion, presenting the project in class as preferred and discussion.

Berdasarkan fakta lapangan dan berbagai pemikiran, penelitian tindakan kelas berjudul "Kasus: Kualitas Konten Tulisan Peserta Didik melalui Penerapan Model Project Based Learning pada Pembelajaran Biologi”. Tujuan penelitian untuk meningkatkan kualitas konten tulisan peserta didik kelas XI MIPA 6 SMA Negeri 4 Surakarta.

\section{Metode Penelitian}

Penelitian adalah Penelitian Tindakan Kelas (PTK) yang dilaksanakan selama 3 siklus. Subjek penelitian berjumlah 32 peserta didik, terdiri dari 15 peserta didik laki-laki dan 17 peserta didik perempuan. Teknik pengumpulan data menggunakan observasi, wawancara, dan dokumentasi.

Data utama penelitian berupa tulisan peserta didik dianalisis dengan rubrik writing skills menurut Mclean, et al. (2012) pada indikator konten. Indikator konten pada rubrik writing skills terdiri dari level 1 sampai 5 yang setiap level memiliki kriteria skor dari 1 sampai 5 .

Uji validasi data dilakukan dengan menggunakan teknik triangulasi data. Teknik analisis data dilakukan dengan: reduksi data, penyajian data, dan penarikan kesimpulan atau verifikasi (Sugiyono, 2013). Prosedur penelitian menggunakan model spiral berdasarkan Suharsimi Arikunto, yang terdiri dari 4 tahapan, yaitu: perencanaan, pelaksanaan, observasi, dan refleksi (Paizaluddin \& Ermalinda, 2013).

\section{Hasil dan Pembahasan}

Hasil observasi selama penerapan model PjBL di siklus 1 sampai dengan 3 menunjukkan adanya peningkatan kualitas konten tulisan peserta didik dibandingkan pratindakan. Peningkatan kualitas konten tulisan teridentifikasi dari hasil tulisan peserta didik di setiap kegiatan pembelajaran $P j B L$ yang diketahui tidak difasilitasi pada proses pembelajaran pratindakan.

Proses pembelajaran $P j B L$ memfasilitasi peserta didik untuk lebih sering menyusun tulisan di setiap tahapan dengan serangkaian kegiatan (Larasati, 2015). Hasil analisis kualitas konten tulisan peserta didik pada setiap kegiatan pembelajaran dalam tahapan model $P j B L$ ditunjukkan pada Gambar 1, 2, 3, 4, dan 5.

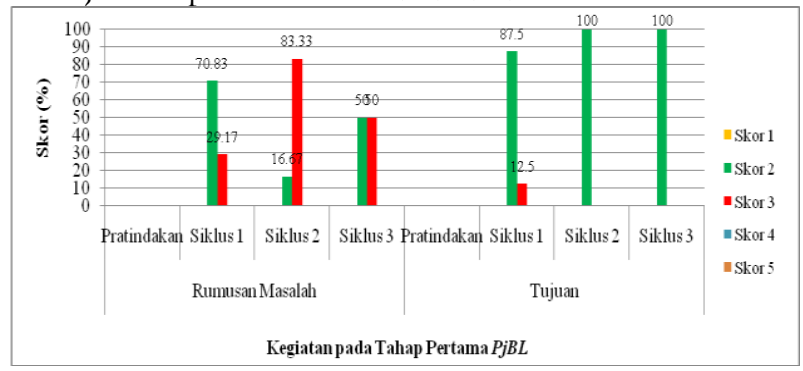

Gambar 1. Kualitas konten tulisan peserta didik di setiap kegiatan pada tahap pertama PjBL 


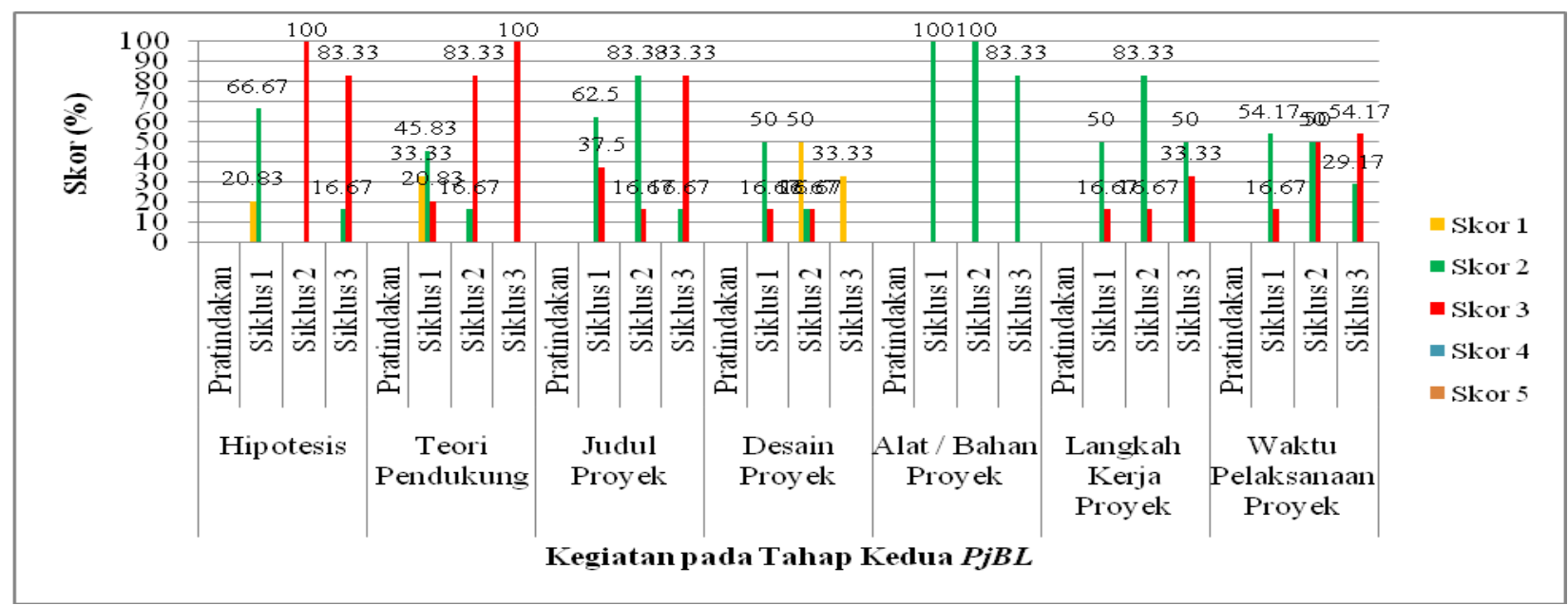

Gambar 2. Kualitas Konten Tulisan Peserta Didik di Setiap Kegiatan pada Tahap Kedua PjBL

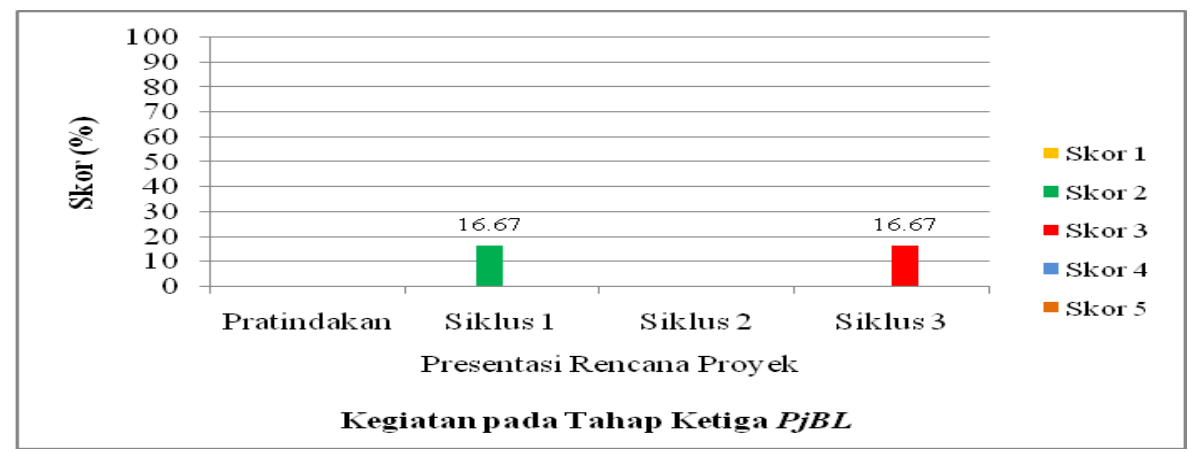

Gambar 3. Kualitas Konten Tulisan Peserta Didik di Kegiatan pada Tahap Ketiga PjBL

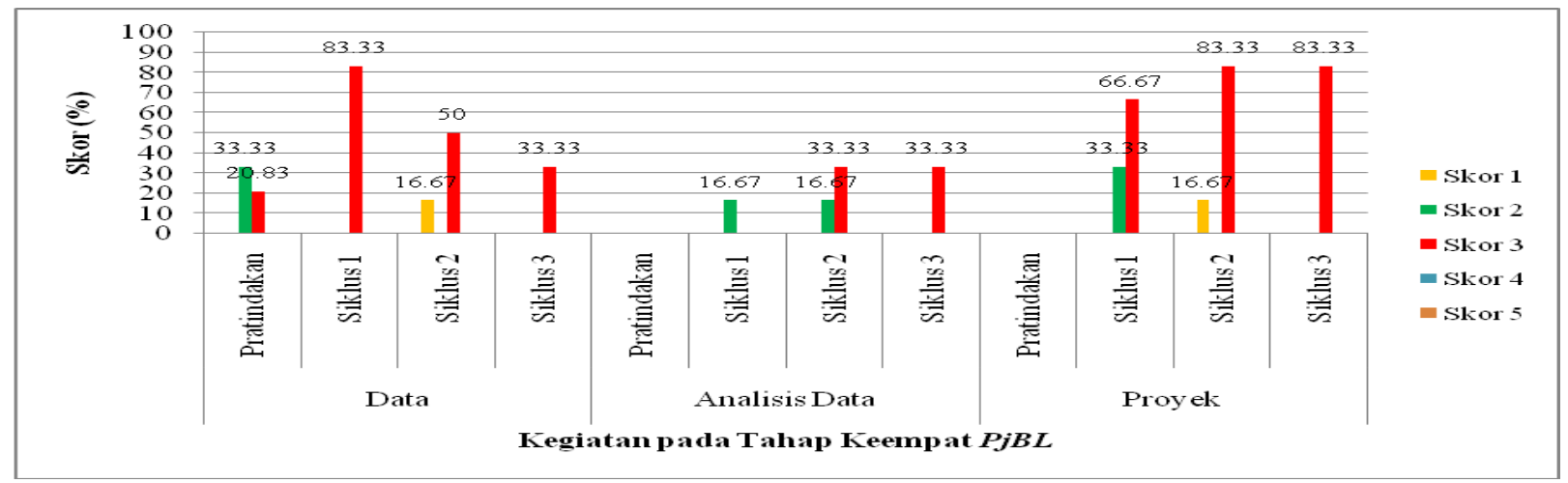

Gambar 4. Kualitas Konten Tulisan Peserta Didik di Setiap Kegiatan pada Tahap Keempat PjBL

Gambar 1, 2, 3, 4, dan 5 menunjukkan perolehan skor kualitas konten tulisan peserta didik pada setiap kegiatan pembelajaran di pratindakan sampai dengan siklus 3 yang terlihat mengalami perubahan. Kualitas konten tulisan peserta didik yang teridenfikasi terdapat pada level 1.

Kualitas konten tulisan pratindakan tidak teridentifikasi pada seluruh kegiatan kecuali kegiatan mengumpulkan data yang diketahui tidak ada tindak lanjut. Kualitas konten tulisan yang tidak terdentifikasi dikarenakan tidak ada produk tulisan yang dihasilkan peserta didik, dengan demikian pembelajaran pratindakan belum memfasilitasi peserta didik melaksanakan serangkaian kegiatan seperti merumuskan masalah, menentukan tujuan pembelajaran, menyusun hipotesis, dan yang tersebut pada kegiatan dalam tahapan model PjBL.

Tahap pertama $P j B L$ memberikan kesempatan peserta didik memvisualisasikan ide dalam bentuk tulisan mengenai rumusan masalah dan tujuan pembelajaran. Tahap kedua $P j B L$ memberikan kesempatan peserta didik memvisualisasikan ide dalam bentuk tulisan mengenai rencana proyek yang terdiri dari: hipotesis, teori pendukung, judul proyek, desain proyek, alat dan bahan proyek, langkah kerja proyek serta waktu pelaksanaan proyek. Tahap ketiga $P j B L$ memberikan kesempatan peserta didik memvisualisasikan ide dalam bentuk tulisan mengenai saran perbaikan rencana proyek yang dipresentasikan. Tahap keempat $P j B L$ memberikan kesempatan peserta didik memvisualisasikan ide dalam bentuk tulisan 
mengenai data diskusi, analisis data, dan proyek. Tahap kelima $P j B L$ memberikan kesempatan peserta didik memvisualisasikan ide dalam bentuk tulisan mengenai kesimpulan dan evaluasi hasil proyek.

Tulisan pada tahap pertama PjBL yang teridentifikasi dari hasil kegiatan merumuskan masalah dan menentukan tujuan pembelajaran didasarkan pada hasil pengamatan peserta didik terhadap kasus yang dihadirkan. Kasus yang dihadirkan di awal pembelajaran merupakan bagian dari kegiatan pramenulis, yang menstimulasi peserta didik untuk mulai menyusun tulisan (Larasati, 2015). Tulisan dari kegiatan merumuskan masalah di siklus 1 sampai 3 teridentifikasi kualitas konten tulisan pada skor 2 dan 3, dengan jumlah masing-masing skor yang mengalami peningkatan secara fluktuatif. Tulisan dari kegiatan menentukan tujuan pembelajaran di siklus 1 sampai 3 teridentifikasi kualitas konten tulisan yang secara umum didominasi skor 2 .

Tulisan pada tahap kedua $P j B L$ yang teridentifikasi dari hasil kegiatan penyusunan perencanaan proyek oleh peserta didik secara berkelompok terlihat memiliki skor kualitas konten tulisan yang berbeda di masing-masing aspek. Aspek hipotesis teridentifikasi mengalami peningkatan skor kualitas konten tulisan secara fluktuatif dari siklus 1 sampai 3 , dengan didominasi oleh skor 3. Aspek teori pendukung teridentifikasi mengalami peningkatan skor kualitas konten tulisan secara kontinu dari siklus 1 sampai siklus 3, yakni 100\% pada skor 3. Aspek judul proyek teridentifikasi kualitas konten tulisan pada skor 2 dan 3 dengan jumlah masingmasing skor mengalami peningkatan secara fluktuatif dari siklus 1 sampai 3. Aspek desain proyek di siklus 1 mengalami peningkatan kualitas konten tulisan dibandingkan pratindakan, ditunjukkan dengan teridentifikasi $50 \%$ pada skor 2 dan $16,67 \%$ pada skor 3 , namun mengalami penurunan jumlah pada skor 2 di siklus 2 dan 3, serta penurunan jumlah pada skor 3 di siklus 3. Aspek alat dan bahan proyek teridentifikasi kualitas konten tulisan pada skor 2 selama di siklus 1 sampai 3. Aspek langkah kerja proyek dan waktu pelaksanaan proyek di siklus 1 sampai 3 teridentifikasi kualitas konten tulisan pada skor 2 dan 3. Kualitas konten tulisan pada skor 2 mendominasi pada aspek langkah kerja, sementara kualitas konten tulisan pada skor 3 mendominasi pada aspek waktu pelaksanaan proyek.

Tulisan pada tahap ketiga $P j B L$ yang teridentifikasi dari hasil kegiatan presentasi perencanaan proyek di siklus 1 sampai 3 terlihat mengalami peningkatan kualitas konten tulisan secara fluktuatif. Kualitas konten tulisan di siklus 1 mengalami peningkatan secara signifikan dibandingkan pratindakan dengan teridentifikasi pada skor 2 , namun di siklus 2 mengalami penurunan. Kualitas konten tulisan di siklus 3 mengalami peningkatan dibandingkan siklus 1 dan 2 dengan teridentifikasi pada skor 3 .
Tulisan pada tahap keempat PjBL yang teridentifikasi dari hasil kegiatan pengerjaan proyek terlihat memiliki kualitas konten tulisan yang berbeda di masing-masing aspek, yakni pengumpulan data, analisis data, dan pembuatan produk. Aspek pengumpulan data dari siklus 1 sampai 3 teridentifikasi mengalami peningkatan skor kualitas konten tulisan secara fluktuatif, dengan hasil akhir terdapat pada skor 3. Aspek analisis data teridentifikasi mengalami peningkatan skor kualitas konten tulisan secara kontinu dari siklus 1 sampai 3, yakni pada skor 3. Aspek pembuatan produk dari siklus 1 sampai 3 teridentifikasi mengalami peningkatan skor kualitas konten tulisan secara fluktuatif, dengan selalu didominasi oleh skor 3 .

Tulisan pada tahap kelima $P j B L$ yang teridentifikasi dari hasil kegiatan merumuskan kesimpulan dan mengevaluasi hasil proyek terlihat memiliki kualitas konten tulisan yang berbeda. Tulisan dari hasil kegiatan merumuskan kesimpulan terlihat mengalami peningkatan skor kualitas konten tulisan secara kontinu dari siklus 1 sampai 3, yakni dengan hasil akhir teridentifikasi pada skor 4. Tulisan dari hasil kegiatan mengevaluasi hasil proyek di siklus 1 sampai 3 terlihat mengalami peningkatan skor kualitas konten tulisan secara fluktuatif, dengan didominasi oleh skor 3 .

Kualitas konten tulisan peserta didik yang teridentifikasi mengalami penurunan pada beberapa kegiatan dalam tahapan model $P j B L$ diduga karena peserta didik belum terbiasa melaksanakan serangkaian kegiatan pembelajaran yang kompleks, akibatnya: 1) peserta didik merasa kurang percaya diri untuk memvisualisasikan ide dalam bentuk tulisan (Baaijen, Galbraith, \& de Glopper, 2014), 2) kesulitan dalam menganalisis informasi yang mempengaruhi kemampuan peserta didik untuk memvisualisasikan pemahaman yang kritis dalam bentuk tulisan (Bailey, et al., 2015).

Serangkaian kegiatan kompleks yang dijumpai pada setiap tahapan model $P j B L$ memberikan kesempatan lebih banyak pada peserta didik untuk menyusun tulisan yang mampu memberikan pengaruh pada hasil tulisan sehingga lebih berkualitas (Chikita, et al., 2013). Pelaksanaan kegiatan kompleks pada setiap tahapan model PjBL menekankan pada tugas-tugas bermakna untuk mampu menghasilkan produk nyata yang melatihkan peserta didik untuk mengembangkan kualitas ide melalui penghubungan konsep pengetahuan dari berbagai prinsip ilmu (Karina, Sadia, \& Suastra, 2014; Thomas, 2000). Kualitas ide yang berkembang mempengaruhi hasil tulisan pada indikator konten karena kualitas konten tulisan memiliki keterkaitan dengan kualitas ide, pemahaman topik yang dipilih, dan penataan ide pada produk tertulis sebagai penilaian kemampuan kognitif (Chikita, et al., 2013)

\section{Simpulan}

Hasil penelitian disimpulkan bahwa ada peningkatan kualitas konten tulisan peserta didik melalui penerapan model PjBL pada pembelajaran Biologi di 
kelas XI MIPA 6 SMA N 4 Surakarta. Peningkatan kualitas konten tulisan peserta didik terjadi secara fluktuatif di setiap siklus dan signifikan dibandingkan pratindakan.

\section{Daftar Pustaka}

Baaijen, V. M., Galbraith, D., \& de Glopper, K. 2014. Effects of Writing Beliefs and Planning on Writing Performance. Elsivier, 33, 81-91.

Bailey, A., et al. 2015. Building a scholar in writing (BSW): A model for developing students' critical writing skills. Elsivier, 15, 524-529.

Brown, S. W., Lawless, K. A., \& Boyer, M. A. 2013. Promoting Positive Academic Dispositions Using a Webbased PBL Environment: The GlobalEd 2 Project. Interdisciplinary Journal of Problem-Based Learning, 6790.

Cakiroglu, U. 2014. Enriching Project-Based Learning Environments with Virtual Manipulatives: A Comparative Stud. Eurasian Journal of Educational Research, 201-222.

Chakravarthi, S., \& Haleagrahara, N. 2010. Implementation of PBL Curriculum Involving Multiple Disciplines in Undergraduate Medical Education Programme. International Education Studies, 165-169.

Chikita, G., Padmadewi, N. N., \& Suarnajaya, I. W. 2013. The Effect of Project Based Learning and Students' Perceived Learning Discipline toward The Writing Competency of The Eleventh Grade Students of SMAN 5 Mataram in The Academic Year 2012/2013. e-Journal Program Pascasarjana Universitas Pendidikan Ganesha, 1, $1-11$.

Demirbag, M., \& Gunel, M. 2014. Integrating ArgumentBased Science Inquiry with Modal Representations: Impact on Science Achievement, Argumentation, and Writing Skills. Educational Sciences: Theory \& Practice, 386-391.

Dwyer, C., Hogan, M., \& Stewart, I. 2011. The Promotion of Critical Thinking Skills through Argument Mapping. Nova Science Publisher, Inc., 4, 1-25.

Karina, N. K., Sadia, I. W., \& Suastra, I. W. 2014. Pengaruh Pembelajaran Berbasis Proyek terhadap Kemampuan Pemecahan Masalah dan Kecerdasan Emosional Siswa SMP. e-Journal Program Pascasarjana Universitas Pendidikan Ganesha, 4, 1-10.

Kyllonen, P. C. 2012. Measurement of 21st Century Skills Within the Common Core State Standards. Invitational Research Symposium on Technology Enhanced Assessment, hlm. 1-24, Educational Testing Service.

Larasati, A. 2015. Improving Students' Writing Skills through Project Based Learning Technique at Grade XI of SMA N 2 Sleman in The Academic Year of 2014/2015. Tesis unpublishe. Yogyakarta: Yogyakarta State University.

Lestari, S. 2009. Upaya Meningkatkan Keterampilan Menulis Siswa dengan Pendekatan Kontekstual. Tesis Tidak Dipublikasikan. Surakarta: Pasca Sarjana, Universitas Sebelas Maret.
Mclean, P., et al. 2012. Australian Core Skills Framework: 5 core skills, 5 levels of performance, 3 domains of communication. Australia: ACEReSearch.

Paizaluddin, \& Ermalinda. 2013. Penelitian Tindakan Kelas (Classroom Action Research) Panduan Teoritis dan Praktis. Bandung: Alfabeta, cv.

Quitadamo, I. J., \& Kurtz, M. J. 2007. Learning to Improve: Using Writing to Increase Critical Thinking Performance in General Education Biology. CBE-Life Sciences Education, 6, 140-154.

Suciu, L., Simon, S. \& Kilyeni, A. 2014. Developing The PR Students' Written Communication Skills. Procedia Social and Behavioral Sciences, 191, 709 - 712.

Sugiyono. 2013. Memahami Penelitian Kualitatif. Bandung: Alfabeta, cv.

Thanh Huy, N. 2015. Problems Affecting Learning Writing Skill Of Grade 11 at Thong Linh High School. Asian Journal of Education Research, 3 (2), 53-69.

Thomas, J. W. 2000. A Review of Research on Project Based Learning. San Rafael, California: The Autodesk Foundation.

Turgut, H. 2008. Prospective Science Teachers' Conceptualizations about Project Based Learning. International Journal of Instruction, 61-79.

Yusefni, W., \& Sriyati, S. 2015. Analisis Hubungan Aktivitas Writing to Learn dengan Kemampuan Berkomunikasi Lisan Siswa dalam Pembelajaran Science Writing Heuristic. Prosiding Simposium Nasional Inovasi dan Pembelajaran Sains 2015 (SNIPS 2015) (pp. 585 - 588). Bandung: Indonesian University of Education Press. 